\title{
PERAN NEGARA DALAM PENDIDIKAN POLITIK PERSPEKTIF GENDER
}

\author{
Nila Sastrawaty \\ Fakultas Syariah dan Hukum, UIN Alauddin Makassar \\ Email: nila.sastrawati@uin-alauddin.ac.id
}

\begin{abstract}
Abstrak:
Artikel ini mengungkapkan bagaimana peran negara dalam pendidikan politik perspektif gender. Bahan analisis yang dibahas dalam tulisan ini bersumber dari riset kepustakaan (library research), dengan menggunakan pendekatan kualitatif fenomenologi, dan analisis menggunakan analisis konten. Paradigma sensitivitas gender dalam politik beranjak dari pemahaman bahwa ranah politik tidak terlepas dari relasi-relasi pelibatan laki-laki dan perempuan. Politik adalah kerja sama (konsensus). Keputusan politik adalah kolektif bukan individu. Sehingga konsep kualitas yang menjadi hal lain dalam melihat kemampuan dan ketidakmampuan, bukanlah milik identitas gender tertentu. Pendidikan politik berbasis sensitivitas gender dapat dicermati; melalui adanya peran negara yang menyediakan regulasi yang mengikat struktur politik. Termasuk dalam bentuk penyelenggaraan pendidikan politik. Implementasi Pendidikan politik pada partai politik melalui program kerja; pada kegiatan sosialisasi dan pelaksanaan program, baik secara langsung maupun melalui komunikasi media. Negara melalui regulasi menyediakan perangkat/instrumen sistem politik yang ideal, menjamin hak, dan kewajiban warga negara serta pelaksanaan pendidikan politik berbasis sensitivitas gender.
\end{abstract}

\begin{abstract}
:
This article reveals how the state plays a role in gender perspective political education. The analytical materials discussed in this paper are sourced from library research, using qualitative phenomenological approaches, and analysis using content analysis. The paradigm of gender sensitivity in politics goes from the understanding that the political realm is inseparable from the relationships of male and female involvement. Politics is cooperation (consensus). Political decisions are collective rather than individual. The concept of quality that becomes another thing in seeing abilities and disabilities, does not belong to a particular gender identity. Political education based on gender sensitivity can be observed; through the role of the state that provides regulations that bind political structures. Included in the form of political education. Implementation of political education in political parties through work programs; socialization and program implementation activities, either directly or through media communication. The state through regulation provides the ideal political system tools/instruments, guarantees the rights, and obligations of citizens as well as the implementation of gender sensitivity-based political education.
\end{abstract}

Keywords: Politic; Gender 


\section{PENDAHULUAN}

Pendidikan Politik merupakan upaya membentuk pemikiran dan orientasi politik individu tentang isu-isu politik yang penting, dan berkembang dalam masyarakat. Dinamika tingkat partisipasi politik, kemampuan masyarakat menyikapi isu-isu politik, memahami pentingnya relasi gender dalam politik, menjadi factor penting mengapa Pendidikan politik perlu dilakukan. Haines mengungkapkan bahwa spesialisasi pada pendidikan tinggi membuat orang menjadi kurang kompoten dalam bidang yang tidak sesuai dengan spesialisasinya (Affandi and Suryadi 2017) sehingga akan mempengaruhi minatnya terhadap bidang yang lain, termasuk dalam politik.

Realitas politik adanya masyarakat yang menarik diri (apatis) dari aktifitas politik menjadi perhatian penting dalam mengkaji peningkatan pengetahuan politik masyarakat melalui pendidikan politik. Dalam konteks demokrasi, keterlibatan rakyat dalam proses pembangunan tanpa adanya dimana warga negara atau rakyat memiliki hak dan kewajiban yang sama dalam kesuksesan jalannya pembangunan, serta mengawal kemajuan sebuah negara melalui partisipasi rakyat. Hal ini menunjukkan bahwa, setiap keputusan negara merupakan bagian dari keinginan rakyat serta berlandaskan kepentingan rakyat. Indonesia sebagai negara yang menganut sistem demokrasi, menempatkan partisipasi rakyat secara tegas dalam Undang-Undang Dasar 1945 Pasal 2 yang telah di amandemen bahwa, "Kedaulatan negara berada ditangan rakyat dan dilaksanakan menurut Undang-Undang Dasar". Negara mengakui kedaulatan rakyat melalui pelibatan dan pengikutsertaan rakyat dalam pengambilan keputusan politik atau kebijakan politik.

Sejumlah regulasi sebagai landasan yuridis pengakuan negara bagi pelaksanaan partisipasi politik warga negara, antara lain; dalam Undang-Undang Dasar 1945, Pasal 28C ayat 2 bahwa "setiap orang berhak untuk memajukan dirinya dalam memperjuangkan haknya secara kolektif untuk membangun masyarakat, bangsa, dan negaranya. Pasal 28D ayat 3 bahwa. "Setiap warga negara berhak memperoleh kesempatan yang sama dalam pemerintahan. Pasal 28E ayat 3 tentang hak atas kebebasan berserikat, berkumpul, dan mengeluarkan pendapat. Penjabaran dari UUD 1945 tentang pengakuan negara terhadap partisipasi rakyat tertuang dalam undang-undang sebagai jaminan pelaksanaan partisipasi rakyat, antara lain; dalam Undang-Undang Nomor 12 Tahun 2005 tentang jaminan dan perlindungan atas hak- 
hak sipil dan politik yang diberikan negara. Undang-Undang Nomor 2 tahun 2008 tentang Partai Politik, serta undang-undang lainnya yang memuat pelaksanaan pemilihan dan pengangkatan dalam jabatan politis (UU No.12, 2005).

Partisipasi masyarakat dalam politik mengalami pasang surut sesuai dinamika politik yang berkembang. Pada periode tertentu, partisipasi politik masyarakat tergolong rendah dan pilihan golput cukup signifikan, dan pada periode tertentu tingkat partisipasi politik rakyat cenderung meningkat dan pilihan golput masyarakat rendah. Realitas tersebut dapat dilihat dari data yang disajikan merdeka.com sebagai berikut;

Tingkat Partisipasi Politik dan Pilihan Golput

$\begin{array}{clcc}\text { No } & \text { Pemilu } & \begin{array}{r}\text { Tingkat Partisipasi } \\ \text { (\%) }\end{array} & \begin{array}{c}\text { Tingkat Golput } \\ \mathbf{( \% )}\end{array} \\ \mathbf{1} & 1955 & 91,1 & 8,6 \\ \mathbf{2} & 1971 & 96,6 & 3,4 \\ \mathbf{3} & 1977 & 96,5 & 3,5 \\ \mathbf{4} & 1982 & 96,5 & 3,5 \\ \mathbf{5} & 1987 & 96,4 & 3,6 \\ \mathbf{6} & 1992 & 95,1 & 4.92 \\ \mathbf{7} & 1997 & 93,6 & 6,4 \\ \mathbf{8} & 1999 & 92,6 & 7,3 \\ \mathbf{9} & 2004 & 84,1 & 15,9 \\ \mathbf{1 0} & 2005(\mathrm{I}) & 78,2 & 21,18 \\ \mathbf{1 1} & 2005(\mathrm{II}) & 76,6 & 23,4 \\ \mathbf{1 2} & 2009(\mathrm{I}) & 70.7 & 29.3 \\ \mathbf{1 3} & 2009(\mathrm{II}) & 71.7 & 28.3 \\ \mathbf{1 4} & 2014(\mathrm{I}) & 75,2 & 24.8 \\ \mathbf{1 5} & 2014(\mathrm{II}) & 70,19 & 29,1\end{array}$

Menteri Koordinator Bidang Politik, Hukum dan Keamanan (Wiranto) dikutip Mulyadi (2019) mengemukakan bahwa, partisipasi pemilih pada pemilihan umum (Pemilu) yang diselenggarakan anggal 17 April 2019 mengalami peningkatan dan mencapai 80,90\% dimana angka tersebut melampaui target KPU yang sebesar 77,5\%. Peningkatan partisipasi politik warga negara sebesar 80,90\% ini pada dasarnya belum menjadi angin segar dalam perspektif demokrasi penuh sebab masih ada masyarakat yang cenderung belum memiliki minat besar dalam aktivitas politik dengan tidak menggunakan hak dan kewajiban politiknya.

Selain permasalahan pemilih pasif dalam politik, permasalahan ketimpangan gender dalam ranah politik masih menjadi permasalahan penting sampai saat ini. Laporan hasil evaluasi pelaksanaan Pemilu Legislatif tahun 2019 mengalami 
peningkatan khususnya pada keterwakilan perempuan dimana tahun 2014 sebanyak 131 orang, mengalami peningkatan 162 pada Pemilu tahun 2019 (Saputra, 2019). Peningkatan tersebut belum memenuhi amanat undangundang 30\% keterwakilan perempuan dalam politik. Mencermati dari data jumlah perempuan secara kuantitas sebesar 132,89 juta jiwa menunjukkan belum terwakilinya perempuan secara maksimal, baik pada tingkat lokal maupun nasional (Chamamy, dkk, 2019). Realita tersebut memberikan pengaruh terhadap pola relasi gender khususnya dalam pengambilan kebijakan politik. Disadari atau tidak, permasalahan ketimpangan gender tidak hanya membawa pengaruh negatif bagi identitas perempuan, tetapi juga bagi identitas laki-laki yang dianggap kurang memberi ruang bagi perempuan.

Penelitian yang dilakukan terkait tingkat partisipasi politik perempuan dalam aktivitas politik menghasilkan temuan sejumlah faktor internal dan eksternal yang menjadi penyebab rendahnya partisipasi politik dikalangan perempuan pada berbagai tingkatan partisipasi politik. Temuan penelitian gender ini menunjukkan bahwa faktor-faktor tersebut tidak bersifat instan, tetapi membutuhkan proses dan waktu yang panjang untuk dekonstruksi kembali paradigma masyarakat tentang pentingnya relasi gender dalam politik. Untuk membangun paradigma ini, dibutuhkan konsistensi negara dan perangkat politiknya untuk mewujudkan politik berkeadilan gender melalui maksimalisasi pendidikan politik yang berbasis sensitivitas gender.

\section{TINJAUAN PUSTAKA}

\section{a. Gender dalam Wacana Kekuasaan}

Gender merupakan atribut yang dilekatkan pada laki-laki dan perempuan yang terbentuk secara kultural. Dalam analisis sosial, gender mengacu pada seperangkat sifat, peran, tanggung jawab, fungsi, hak dan perilaku yang melekat pada laki-laki dan perempuan (Maksum, 2016). Unsur utama dalam menempatkan pemahaman gender secara keliru yang mengarah pada anatomi biologis yang dikonstruksi dan di terima sebagai suatu kewajaran. Terjadi pergeseran pemaknaan gender sebagai konsep yang secara teoretis tidak berorientasi pada jenis kelamin yang bersifat biologis, kemudian bergeser mengarah pada gender yang bersifat sosial. Jenis kelamin secara biologis adalah pemberian atau kodrat sebagai identitas 
laki-laki dan identitas perempuan. Berdasarkan pembedaan tersebut, berbagai argumentasi feminisme menunjukkan bahwa secara umum terdapat posisi yang berbeda antara laki-laki dan perempuan dalam jaringan relasi sosial dan politik.

Istilah "gender" dalam Kamus Bahasa Inggris diberi makna jenis kelamin dalam konteks sosial, politik, budaya, dan keagamaan yang didasarkan pada fisik perempuan dan laki-laki (Hasyim, 2010). Sedangkan terminologi gender dapat dicermati dalam berbagai perspektif. Fakih menjelaskan bahwa gender merupakan landasan bagi berlangsung satu pranata masyarakat. Persepsi diri laki-laki dan perempuan, apa dan siapa dirinya, alokasi pekerjaan yang diberikan, pembagian wewenang, terpola melalui sistem gender. Pengaturan gender juga dibakukan melalui berbagai institusi yang ada, yang merupakan tempat terjadinya sosialisasi dan internalisasi nilai seperti keluarga, Pendidikan formal, agama, sistem politik, dan sistem ekonomi. Lebih lanjut dijelaskan Fakih, konsep gender adalah suatu sifat yang melekat pada kaum laki-laki dan perempuan yang dikonstruksi secara sosial dan kultural. Perbedaan-perbedaan gender dibentuk, disosialisasikan, diperkuat dan dikonstruksi secara sosial dan kultural melalui ajaran agama maupun negara (Fakih, 1997).

Ideologi patriarkat dan ideologi gender telah merasuki sistem dan struktur nilai dalam masyarakat, menempatkan perempuan dalam posisi marginal (subordinat) sedangkan laki-laki berada pada posisi ordinat. Kondisi demikian mendorong lahirnya diskriminasi sosial, ekonomi, budaya, dan politik, sebab dalam sistem patriarkat terdapat sistem otoritas yang berdasarkan kekuasaan laki-laki.

Penelitian-penelitian gender yang telah dilakukan menunjukkan bahwa bukan hanya kekeliruan menafsirkan al Quran dan Hadits sebagai satu-satunya kendala dalam melihat keterlibatan perempuan dalam wilayah publik termasuk politik, tetapi juga peran budaya lokal masyarakat setempat. Penelitian Agustina \& Heriyani (2009) berkaitan keterwakilan perempuan di parlemen dalam perspektif keadilan dan kesetaraan gender, menunjukkan bahwa terdapat beberapa faktor yang menyebabkan ketimpangan keterwakilan perempuan dalam parlemen, yakni : a) Nilai sosial budaya yang mengutamakan laki - laki. b) Pembagian kerja berdasarkan gender dalam masyarakat agraris-tradisional. c) Citra perempuan sebagai kaum yang lemah lembut. d) Ajaran agama yang ditafsirkan secara sempit dan parsial. e) 
Kurangnya political will pemerintah, dan f) kekurangan dalam kualitas individu perempuan dan kaderisasi politik.

Secara umum, isu-isu gender dalam politik dan menjadi alasan pembenaran keterbatasan identitas gender perempuan dalam ranah politik sebagai berikut;

1) Gender dalam otoritas agama

Islam dan isu kekuasaan menjadi salah satu permasalahan yang melingkupi isu-isu gender dan politik. Keragaman pandangan mengenai perempuan berpolitik menimbulkan dua pandangan yang berbeda dalam menyikapi politik Islam dan isu perempuan. Penelitian-penelitian yang dilakukan pemerhati gender menunjukkan bahwa, penafsiran atas muatan-muatan agama menjadi dialektika dalam mengkaji peran gender dalam ranah publik. Penelitian Kurniasih terkait politik tafsir agama terhadap perempuan menjelaskan bahwa menafsirkan ayat-ayat al Quran dan hadis secara tunggal yang disertai dengan keparsialan dalam menafsirkan akan melahirkan kesempitan dalam memaknai landasan agama bahkan akan menutup makna sebenarnya yang terkandung dalam ayat tersebut. Pandangan tersebut sejalan dengan Murata bahwa gender tidak dapat dipandang secara parsial atau kacamata syariat semata sebab syariat menyampaikan perintah-perintah (Kurniasih, 2009); (Murata, 1996). Dalam rangka mencapai tujuan politik, Al quran dan hadis dijadikan sebagai otoritas penuh untuk menghasilkan makna kebenaran mutlak, sebagai pusat, otoritas, dan subyek (logos) untuk menciptakan kekerasan simbolik. Apa yang diwacanakan ahli agama menjadi pemaksaan secara halus untuk menolak tindakan yang dianggap bertentangan dengan ajaran agama.

2) Gender dan patriarki

Patriarki adalah sebuah sistem sosial yang menempatkan laki-laki sebagai sosok otoritas utama yang sentral dalam organisasi sosial. Posisi laki-laki lebih tinggi dari pada perempuan dalam segala aspek kehidupan sosial, budaya dan ekonomi. Ayah memiliki otoritas terhadap ibu, anak-anak dan harta benda. Secara tersirat sistem ini melembagakan pemerintahan dan hak istimewa laki-laki dan menuntut subordinasi perempuan. Bahkan dinilai sebagai penyebab dari penindasan terhadap perempuan (Pinem, 2009); (Walkins, 2007). Lebih lanjut dikemukakan bahwa patriarki merupakan distribusi kekuasaan antara laki-laki dan perempuan di mana laki-laki memiliki keunggulan dalam satu atau lebih aspek, seperti penentuan garis keturunan (keturunan patrilineal eksklusif dan membawa nama belakang), hak-hak anak sulung, otonomi pribadi 
dalam hubungan sosial, partisipasi dalam status publik dari berbagai pekerjaan pria dan wanita yang ditentukan oleh pembagian kerja secara seksual.

Konsep patriarki yang awalnya berfokus pada peran laki-laki dewasa dalam rumah tangga, melahirkan bentuk dominasi yang lebih luas yakni dalam ranah sosial atau publik, dimana Lembaga-lembaga atau pranata-pranata sosial turut berkontribusi dalam membentuk patriarki baik dalam ranah sosial, ekonomi, maupun politik. Dampaknya kemudian memberi ruang dominasi serta menempatkan perempuan dalam posisi tersubordinasi, dan memberi pengaruh jangka Panjang pada realitas relasi gender.

3). Modalitas politik

Pemahaman konsep modalitas politik mengacu pada Teori Modal yang dicetuskan Piere Bourdieu, dimana teori ini memiliki keterkaitan erat dengan masalah kekuasaan. Pada masyarakat politik masalah dominasi merupakan masalah utama sebagai salah satu bentuk aktualisasi kekuasaan. Bourdieu (1986), dalam bukunya The Forms of Capital, membagi modal ke dalam modal ekonomi, modal budaya, dan modal sosial yang sifatnya dapat dipertukarkan. Bentuk nyata dari modalitas dikemukakan Bourdieu melekat dalam realitas rupa simbolik yang dieksternalisasi sebagai sesuatu yang legitimate.

Modalitas yang dikemukakan Bourdeu terkait dominasi kekuasaan dijabarkan sebagai modalitas politik sebagai berikut; a) Modal ekonomi adalah sumber daya yang bisa menjadi sarana produksi dan sarana finansial, antara lain kepemilikan sarana produksi, dan finansial (uang) yang dapat digunakan untuk mencapai tujuan politik. Proses politik yang panjang mulai dari proses sosialisasi, partisipasi, komunikasi, sampai dengan proses rekrutmen politik membutuhkan kekuatan finansial yang besar. b) Modal kultural/budaya, terkait dengan kualitas intelektual (kecerdasan, tanggung jawab, ketrampilan), pendidikan formal termasuk gelar yang dimiliki, serta kemampuan tampil di tengah masyarakat. c) Modal sosial terkait dengan popularitas dan jaringan atau dukungan masyarakat karena nilai tertentu yang dimiliki sebagai sumber daya.

b. Pendidikan Politik sebagai Fungsi Sosialisasi Politik

Pendidikan politik merupakan kesempatan yang diberikan kepada warga negara sebagai salah satu peningkatan pengetahuan politik yang memotivasi individu dalam aktivitas politik, hal ini dapat dicermati dari pengertian yang dikemukakan para ahli. Kartini Kartono mendefinisikan pendidikan politik sebagai upaya pendidikan yang disengaja dan sistematis untuk membentuk individu agar mampu menjadi partisipan yang bertanggung jawab secara etis/moral dalam pencapaian tujuan politik ( Rusadi Kantaprawira menjelaskan pendidikan politik sebagai upaya 
meningkatkan (Kartono, 1989). Menurut Kantarprawira (2006) pengetahuan politik rakyat agar mereka dapat berpartisipasi secara maksimal dalam sistem politiknya, sesuai dengan paham kedaulatan rakyat atau demokrasi bahwa rakyat harus mampu menjalankan tugas partisipasi. Sedangkan Alfian pendidikan politik adalah usaha yang sadar untuk mengubah proses sosialisasi politik masyarakat sehingga mereka memahami dan menghayati betul nilai-nilai yang terkandung dalam sistem politik yang ideal yang hendak dibangun (Alfian, 1981).

Pengertian yang dikemukakan Kartini, Rusadi, dan Alffian menunjukkan adanya beberapa unsur penting dalam pendidikan politik yakni; pertama, pendidikan politik dilaksanakan secara sengaja (sadar) dengan cara yang sistematis, kedua, memiliki tujuan antara lain peningkatan pengetahuan politik masyarakat dalam partisipasi politik. Ketiga, hasil dari proses sosialisasi politik.

Sosialisasi politik dan pendidikan politik bagi sebagian ahli melihat dua konteks yang hampir sama, jika mengacu pada pengertian pendidikan politik dalam Bahasa Inggris yakni political sosialization atau sosialisasi politik namun dalam arti sempit. Surbakti (1999) membagi sosialisasi politik ke dalam dua aspek yakni; Pendidikan politik, dan indoktrinasi politik. Dalam proses Pendidikan politik berlangsung proses dialogis antara pemberi pesan dan penerima pesan. Melalui proses ini, anggota masyarakat mengenal nilai-nilai, norma-norma, dan simbolsimbol politik dari berbagai pihak dalam sistem politik. Pandangan Surbakti ini menempatkan pendidikan politik sebagai bagian dari sosialisasi politik. Bagaimana menanamkan nilai-nilai, norma, dan pengetahuan politik yakni melalui sosialisasi politik.

Bentuk sosialisasi politik dibedakan dalam dua perspektif, yakni; teaching perspective, dan learning perspective. Teaching perspective atau sosialisasi satu arah merupakan sikap yang ditunjukkan dari sasaran sosialisasi bersifat pasif atau cenderung satu arah karena bergantung pada pemateri, tanpa memberikan respon atau tanggapan balik dari audiens. Sedangkan learning perspective, sasaran dari sosialisasi politik bersifat aktif dan tiap individu memiliki kesempatan untuk mengembangkan diri selama proses sosialisasi politik, dalam hal ini setiap individu diberikan kesempatan untuk mengutarakan segala yang ingin diungkapkan seperti kritikan ataupun menolak materi (Haryanto, 2018).

Pendidikan politik sebagai proses yang dilangsungkan secara sadar dan 
bertujuan dimaksudkan bahwa proses tersebut dilakukan secara terencana dengan ketersediaan instrumen-instrumen politik dan berlangsung dalam sebuah relasirelasi sosial. Konsepsi tindakan bertujuan terkait dengan konsep pilihan rasional dalam kajian sosiologi. Dalam relasi sosial setiap aktor memiliki motivasi tertentu, demikian halnya dalam politik. Politik sebagaimana didefinisikan Harold D Lasswell bahwa batasan politik sebagai "apa yang mendapatkan apa, kapan, dan bagaimana", menuntun individu untuk melakukan berbagai upaya untuk memperoleh tujuan yang dikehendakinya. Hal ini menunjukkan bahwa, dalam proses pendidikan politik menghasilkan paduan dari pengetahuan, sikap, dan perilaku.

Affandi (2012) menguraikan tiga aspek hasil dari pendidikan politik, yakni dari aspek pengetahuan meliputi; 1). informasi dasar terkait pemegang kekuasaan, modal finansial, dan bagaimana institusi bekerja . 2). Bagaimana memanfaatkan pengetahuan yang dimiliki. 3). Kemampuan dalam penanganan isu. 4). Kemampuan mengenal kebijakan secara baik yang dapat dicapai Ketika isu telah ditangani. 5). Kemampuan memahami pandangan orang lain dan memahami tindakannya. Aspek terkait sikap meliputi; toleransi, menghargai kebenaran, menghargai pemikiran, dan kebebasan. Sedangkan aspek ketrampilan terkait konsistensi terhadap pilihannya terkait kemampuan berpartisipasi aktif, dan atau sebaliknya menjadi individu pasif dalam politik. Pandangan Alffian mempertegas bahwa pendidikan politik memiliki arti penting yang berujung pada partisipasi politik warga negara.

Dalam perspektif sosiologi politik, partisipasi politik merupakan aktivitas sukarela warna masyarakat dalam sejumlah aktivitas politik. Dari beberapa definisi partisipasi yang telah dikemukakan, maka terdapat hal - hal substantif berkaitan dengan partisipasi politik, sebagai berikut:

1. Kegiatan-kegiatan nyata atau kegiatan yang dapat diamati secara langsung

2. Bersifat sukarela, dimana kegiatan yang dilakukan tidak mengandung paksaan tetapi merupakan kesadaran sendiri. Tidak digerakkan oleh pihak mana pun baik perseorangan, kelompok, maupun pemerintah

3. Dilakukan oleh warga Negara biasa atau masyarakat biasa, baik individu maupun kelompok masyarakat

4. Memiliki tujuan ikut serta dalam kehidupan politik, mempengaruhi kebijakan pemerintah, bahkan mencari jabatan politik 
5. Memiliki tingkatan-tingkatan partisipasi, mulai pada tingkatan terendah sampai pada tingkatan tertinggi.

Individu-individu memperoleh orientasi politik sebagai dasar pola perilaku politiknya melalui sosialisasi politik dalam rangka mengenal gejala sosial dan politik yang terjadi dalam masyarakat. Oleh sebab itu, sering kali dikemukakan bahwa tinggi rendahnya partisipasi politik dalam sebuah masyarakat tergantung pada berhasil tidaknya proses sosialisasi politik yang dilakukan. Komunikasi politik merupakan bagian penting dari efektivitas sosialisasi politik. Lalu, sejauh mana komunikasi politik mampu menjadi sumber informasi politik bagi masyarakat, mengingat informasi timbal balik antara penguasa dan masyarakat sangat penting. Pertanyaan tersebut sangat berhubungan dengan hubungan komunikasi dengan politik. Jawabannya adalah komunikasi politik yang mempertimbangkan kondisi-kondisi pribadi dan kondisi sosial masyarakat.

\section{METODE PENELITIAN}

Data yang menjadi bahan analisis pembahasan dalam tulisan ini bersumber dari riset kepustakaan (library research), dengan menggunakan pendekatan kualitatif fenomenologi. Fenomenologi merupakan salah satu pendekatan yang digunakan dalam penelitian kualitatif yang berupaya untuk menangkap berbagai persoalan yang ada di masyarakat dan mengungkap makna yang terkandung di dalamnya. Anaisis data menggunakan analisis konten yaitu proses analisis terhadap data diperoleh melalui literatur berupa buku, jurnal, dokumen pribadi, media massa, serta mengolah data dari beberapa hasil penelitian terkait fokus pembahasan dalam artikel ini. yang kemudian ditarik sebuah kesimpulan.

\section{HASIL DAN DISKUSI}

Pemahaman terhadap makna gender masih menjadi permasalahan di tengah masyarakat sebagai identitas jenis kelamin laki-laki dan perempuan, istilah yang dianggap tidak islami, dan dianggap paham dari belahan dunia tertentu. Kekeliruan pemahaman ini bukan hanya di kalangan masyarakat awam tetapi juga di kalangan masyarakat dengan tingkat pendidik yang memadai. Hal tersebut dapat diamati dalam kelompok-kelompok diskusi yang melibatkan sejumlah kalangan masyarakat. 
Permasalahan dalam wacana politik tidak terlepas dari relasi politik yang melibatkan peran laki-laki dan perempuan, menjadi kajian khusus bagi peneliti dan penggiat gender. Permasalahan utama terletak pada konstruksi sosial yang memberi pembeda peran laki-laki dan perempuan khususnya dalam ranah publik termasuk dalam politik. Perilaku politik dipandang sebagai aktivitas maskulin atau ranahnya laki-laki. Siti Musdah Mulia mengemukakan bahwa selama ini, politik dan perilaku politik dipandang sebagai aktivitas maskulin. Perilaku politik yang dimaksud di sini mencakup kemandirian, kebebasan berpendapat, dan tindakan agresif. Ketiga karakteristik tersebut tidak pernah dianggap ideal dalam diri perempuan. Dengan kata lain karakteristik tersebut adalah milik laki-laki (Mulia, SM \& Farida, 2005).

Realitas gender juga menunjukkan perempuan turut memberi kontribusi dalam melegalkan pandangan masyarakat bahwa yang dialami perempuan adalah sesuatu yang wajar. Sejumlah faktor menjadi penyebab, di antaranya pandangan yang mengusung konteks agama sebagai pembenaran. Konstruksi atas nama agama yang ditafsirkan secara keliru menjadikan tafsiran al Quran dan Hadis pada tafsiran yang tidak tepat, tetapi masyarakat menganggap agama sebagai legalitas yang tidak dapat dibantah. Di samping itu, modalitas politik termasuk kontribusi budaya bagi perempuan yang terbatas memberi kontribusi keraguan masyarakat memberikan pengakuan objektif kemampuan perempuan dalam urusan politik. Negara dan sejumlah kalangan (partai politik, dan kelompok/lembaga pemerhati gender) melakukan serangkaian gerakan afirmasi (affirmasi action) sebagai upaya mendorong orientasi politik berbasis sensitivitas gender.

Sensitivitas gender adalah proses di mana orang disadarkan tentang bagaimana gender memainkan peran dalam kehidupan melalui perlakuan mereka terhadap orang lain. Paradigma sensitivitas gender dalam politik beranjak dari pemahaman bahwa ranah politik tidak terlepas dari relasi-relasi pelibatan laki-laki dan perempuan. Politik adalah kerja sama (consensus), keputusan politik adalah keputusan kolektif bukan individual, sehingga konsep kualitas (kecerdasan, tanggung jawab, kepercayaan) yang menjadi unsur lain dalam melihat kemampuan dan ketidakmampuan bukan milik identitas gender tertentu.

Peran negara dalam pendidikan politik berbasis sensitivitas gender melalui legitimasi atau regulasi yang mengikat unsur-unsur yang terlibat dalam proses politik, dengan menyediakan regulasi yang mendorong upaya maksimalisasi 
keterlibatan identitas gender perempuan dalam politik;

1) Perubahan Undang-Undang Dasar (UUD) Negara Republik Indonesia Tahun 1945 yaitu pasal $28 \mathrm{H}$ ayat (2) yang menyatakan "Setiap orang berhak mendapatkan kemudahan dan perlakuan khusus untuk memperoleh kesempatan dan manfaat yang sama guna mencapai persamaan dan keadilan".

2) Undang-Undang Nomor 22 Tahun 2007 tentang Penyelenggara Pemilu, - pasal 6 ayat (5), "Komposisi keanggotaan KPU, KPU Provinsi, dan KPU Kabupaten/Kota memperhatikan keterwakilan perempuan sekurang-kurangnya 30\% (tiga puluh perseratus).

- Pasal 43 ayat (3), "Komposisi keanggotaan PPK memperhatikan keterwakilan perempuan sekurang-kurangnya 30\% (tiga puluh perseratus)".

- Pasal 73 ayat (8), "Komposisi keanggotaan Bawaslu, Panwaslu Provinsi, dan Panwaslu Kabupaten/Kota memperhatikan keterwakilan perempuan sekurang-kurangnya 30\% (tiga puluh perseratus)".

3) Undang-Undang Nomor 2 Tahun 2008 tentang Partai Politik.

- $\quad$ Bab II, pasal 2 ayat (2), "Pendirian dan pembentukan Partai Politik sebagaimana dimaksud pada ayat (1) menyertakan 30\% (tiga puluh perseratus) keterwakilan perempuan".

- Pasal 20, "Kepengurusan Partai Politik tingkat provinsi dan kabupaten/kota sebagaimana dimaksud dalam Pasal 19 ayat (2) dan ayat (3) disusun dengan memperhatikan keterwakilan perempuan paling rendah 30\% (tiga puluh perseratus) yang diatur dalam AD dan ART Partai Politik masing-masing".

4) Undang-Undang Nomor 10 Tahun 2008 tentang Pemilu DPR, DPD, dan DPRD

- $\quad$ Pasal 8 ayat (1) bagian (d), "menyertakan sekurang-kurangnya 30\% (tiga puluh perseratus) keterwakilan perempuan pada kepengurusan partai politik tingkat pusat;

- Pasal 15, bagian (d), "surat keterangan dari pengurus pusat partai politik tentang penyertaan keterwakilan perempuan sekurang- 
kurangnya 30\% (tiga puluh perseratus) sesuai dengan peraturan perundang-undangan;

- Pasal 53, "Daftar bakal calon sebagaimana dimaksud dalam Pasal 52 memuat paling sedikit 30\% (tiga puluh perseratus) keterwakilan perempuan".

- Pasal 55 ayat (2), "Di dalam daftar bakal calon sebagaimana dimaksud pada ayat (1), setiap 3 (tiga) orang bakal calon terdapat sekurang-kurangnya 1 (satu) orang perempuan bakal calon.

- Pasal 57 ayat (1), "KPU melakukan verifikasi terhadap kelengkapan dan kebenaran dokumen persyaratan administrasi bakal calon anggota DPR dan verifikasi terhadap terpenuhinya jumlah sekurang-kurangnya 30\% (tiga puluh perseratus) keterwakilan perempuan

- Pasal 57 ayat (2), "KPU provinsi melakukan verifikasi terhadap kelengkapan dan kebenaran dokumen persyaratan administrasi bakal calon anggota DPRD provinsi dan verifikasi terhadap terpenuhinya jumlah sekurang-kurangnya $30 \%$ (tiga puluh perseratus) keterwakilan perempuan.

- Pasal 57 ayat (3), "KPU kabupaten/kota melakukan verifikasi terhadap kelengkapan dan kebenaran dokumen persyaratan administrasi bakal calon anggota DPRD kabupaten/kota dan verifikasi terhadap terpenuhinya jumlah sekurang-kurangnya 30\% (tiga puluh perseratus) keterwakilan perempuan

- Pasal 58 ayat (2), "Dalam hal daftar bakal calon tidak memuat sekurang-kurangnya $30 \%$ (tiga puluh perseratus) keterwakilan perempuan, KPU, KPU provinsi, dan KPU kabupaten/kota memberikan kesempatan kepada partai politik untuk memperbaiki daftar bakal calon tersebut.

- Pasal 61 ayat (6)," KPU, KPU provinsi, dan KPU kabupaten/kota mengumumkan persentase keterwakilan perempuan dalam daftar calon sementara partai politik masing-masing pada media massa cetak harian nasional dan media massa elektronik nasional.

- Pasal 66 ayat (2), "KPU, KPU provinsi, dan KPU kabupaten/kota 
mengumumkan persentase keterwakilan perempuan dalam daftar calon tetap partai politik masing-masing pada media massa cetak harian nasional dan media massa elektronik nasional.

Keberadaan regulasi ini merupakan upaya pemerintah dalam mendorong peran perempuan dalam politik, dan sebagai penjabaran dari Garis-Garis Besar Haluan Negara (GBHN) Indonesia sebagai haluan dalam penyelenggaraan negara. Pada GBHN dikemukakan bahwa hakikat pembangunan adalah partisipasi aktif segenap lapisan masyarakat dalam pembangunan harus makin meluas dan merata. Pembangunan nasional dilaksanakan bersama oleh masyarakat dan pemerintah. Masyarakat adalah pelaku utama pembangunan dan pemerintah berkewajiban untuk mengarahkan, membimbing, serta menciptakan suasana yang menunjang. Kegiatan masyarakat dan kegiatan pemerintah saling menunjang, saling mengisi, dan saling melengkapi dalam satu kesatuan langkah menuju tercapainya tujuan pembangunan nasional (TAP MPR No. II/MPR/1998).

Gerakan afirmasi yang dilakukan negara melalui penyediaan sejumlah regulasi politik memperkuat peran dan fungsi partai politik sebagai salah satu agen pendidikan politik bagi masyarakat. Dalam Undang-Undang Nomor 2 Tahun 2008 tentang Partai Politik, keharusan partai politik dalam mengakomodir keterwakilan perempuan minimal 30\% baik dalam pendirian maupun kepengurusan pada tingkat pusat. Penekanan lain dalam regulasi tersebut adalah bahwa partai politik harus memenuhi persyaratan minimal 30\% keterwakilan perempuan dalam daftar bakal calon, mulai tingkat pusat, wilayah, sampai tingkat daerah.

Pada internal partai politik, gerakan afirmasi bagi perempuan tertuang dalam Anggaran Dasar dan Anggaran Rumah Tangga (AD/ART) partai politik, meliputi;

a) Menduduki posisi pengurus harian pada tingkat pusat, wilayah, dan daerah.

b) Menduduki posisi pada sayap organisasi atau badan otonom (keperempuanan)

c) Penegasan persamaan hak perempuan secara proporsional, pemberian kesempatan yang sama secara hukum, sosial, ekonomi, dan politik, dan dituangkan pada pasal khusus.

Bentuk Pendidikan politik yang dapat digunakan dalam mengimplementasikan politik berbasis gender. Kartaprawira mengemukakan 
terdapat beberapa bentuk penyelenggaraan pendidikan politik yang dapat dilakukan, antara lain adalah sebagai berikut: a). Bahan bacaan seperti surat kabar, majalah, dan lain-lain bentuk publikasi massa yang biasa membentuk pendapat umum. b). Siaran radio dan televisi serta film (audio visual media). c). Lembaga atau asosiasi dalam masyarakat seperti masjid atau gereja tempat menyampaikan khotbah, dan juga lembaga pendidikan formal (sekolah) ataupun informal (Kantaprawira, 1999). Implementasi Pendidikan politik pada partai politik melalui program kerja partai antara lain; pada kegiatan sosialisasi dan pelaksanaan program partai.

Penggunaan media massa sebagaimana dikemukakan Kartaprawira masih dianggap efektif dalam Pendidikan politik warganegara. Komunikasi dalam kehidupan politik sarat dengan isu-isu politik di mana penerimaan dan tanggapan politik berbeda antara satu individu dengan individu lain atau antara kelompok satu dengan kelompok lain. Seseorang akan tertarik dan dengan mudah menyerap isu-isu politik yang baru dan cenderung heroik dari pada isu-isu politik yang dianggap telah basi dan monoton. Ketertarikan seseorang mengenai isu-isu politik juga tergantung pada apakah isu tersebut mewakili harapan-harapan dan tujuan politiknya. Dalam kehidupan politik modern, persepsi individu-individu dengan sendirinya telah terspesialisasi pada aspekaspek tertentu, sehingga individu akan memberikan respons besar apabila berhubungan dengan spesialisasi persepsinya. Misalnya, seseorang yang mempunyai harapan-harapan dan tujuan-tujuan politik yang berkaitan dengan jabatan politik, akan memberikan respons yang besar terhadap isu-isu yang berkaitan dengan proses pemilihan dalam jabatan politik.

Media massa dalam wacana politik dapat dilihat pada dua aspek; pertama, Media massa berperan sebagai agen sosialisasi politik melalui informasi politik yang bertujuan pembentukan opini publik. Kedua, bagi aktor politik substansi politik dalam media massa diharapkan dapat mempengaruhi opini khalayak. Membangun orientasi politik masyarakat bukan hal yang mudah sebab di samping keberadaan individu-individu yang dinamis dan kreatif, juga akan berhadapan dengan apatisme dan sinisme politik masyarakat yang tidak sedikit. Oleh sebab itu, dalam komunikasi politik dikemukakan berbagai teori yang dapat menjadi bahan analisis efektivitas proses komunikasi tersebut.

Peran media massa saat ini mendapat porsi yang besar dalam membentuk opini politik publik. Informasi politik yang bervariasi semakin memperkaya pengetahuan 
politik masyarakat. Serangan informasi politik melalui siaran televisi misalnya, mulai dari anak-anak sampai orang dewasa dapat menjadi sumber pesan bagi orang lain berdasarkan informasi yang diperoleh melalui siaran tersebut. Demikian pula informasi politik melalui media cetak, pada kurun waktu tertentu memusatkan isi pemberitaannya pada isu-isu politik yang berkembang dan dianggap menarik untuk menambah pengetahuan politik masyarakat.

Sosiologi Politik memandang media massa sebagai suatu lembaga yang memiliki kekuatan yang besar dalam mengubah tatanan kehidupan. Kekuatan yang demikian besar ini menempatkan media massa sejajar dengan kekuatan perubahan politik lainnya (eksekutif,legislative, dan yudikatif). Pada sistem politik yang melibatkan masyarakat secara langsung khususnya dalam pemilihan jabatan politik, media massa dapat berfungsi sebagai saluran komunikasi politik yang efektif. Pada saat komunikator politik tidak dapat menjangkau seluruh wilayah dalam kurun waktu tertentu, media massa dapat digunakan sebagai saluran penyampaian pesan politik, sehingga muatan Pendidikan politik dapat berlangsung dengan efektif.

\section{KESIMPULAN}

Mengacu pada pembahasan terkait peran negara dalam pendidikan politik berbasis sensitivitas gender dapat disimpulkan bahwa;

a) Paradigma sensitivitas gender dalam politik beranjak dari pemahaman bahwa ranah politik tidak terlepas dari relasi-relasi pelibatan laki-laki dan perempuan. Politik adalah kerja sama (consensus), keputusan politik adalah keputusan kolektif bukan individual, sehingga konsep kualitas (kecerdasan, tanggung jawab, kepercayaan) yang menjadi unsur lain dalam melihat kemampuan dan ketidakmampuan bukan milik identitas gender tertentu.

b) Pendidikan politik berbasis sensitivitas gender dapat dicermati antara lain adanya peran negara menyediakan regulasi yang mengikat struktur politik termasuk partai politik yang diimplementasikan ke dalam bentuk penyelenggaraan pendidikan politik Implementasi Pendidikan politik pada partai politik melalui program kerja partai antara lain; pada kegiatan sosialisasi dan pelaksanaan program partai baik secara langsung maupun melalui media komunikasi. 


\section{DAFTAR PUSTAKA}

Affandi, I. (2012). Pendidikan Politik. Bandung: Mutiara Press; 2012, h. 33-34

Agustina \& Heriyani. (2009). Keterwakilan Perempuan di Parlemen dalam Perspektif Keadilan dan Kesetaraan Gender, dalam Gender dan Politic. Yogyakarta: PSW Univ Gadjah Mada

Alfian. (1981). Pemikiran dan Perubahan Politik Indonesia. Jakarta: Gramedia, 1981, h. 236.

Fakih, Mansoer. (1997) Merekonstruksi Realitas dengan Perspektif Gender (Sekertariat Bersama Perempuan Jogyakarta; Jogjakarta, h. 25.

Haryanto. (2018). Sosiologi Politik suatu Pemahaman Awal (Research Center for Politics and Government (PolGov).Jakarta.

Hasyim, Syafiq. (2010). Bebas dari Patriarkhisme Islam, Cet. I; Depok:Kata Kita, h. 35-37.

Iswary, Ery. (2010). Perempuan Makassar (Penerbit Ombak; Makassar, 2010), h.17

Kantaprawira, R. (1999). Sistem Politik Indonesia; Suatu Model Pengantar. Bandung : Sinar Baru Algensindo., 2006, h. 54

Kartono, K. (1989). Pendidikan politik sebagai bagian dari pendidikan orang dewasa. Mandar Maju.

Kurniasih. (2009).Politik Tafsir Agama Terhadap Perempuan. Yogyakarta; Tiara Wacana

Maksum, Ali. (2016). Sosiologi Pendidikan (Cet I; Malang: Madani, 2016), h. 170

Mulia, S. M. (2005). Perempuan dan politik. Jakarta: Gramedia Pustaka Utama h.1

Mulyadi, Muhammad. (2009). Membangun Demokrasi dengan Partisipasi Masyarakat dalam Memilih Pada Pemilu 2019. Info Singkat: Kajian Singkat Terhadap Isu Aktual dan Strategis, Vol. XI. No.09 (2019), h. 14

Murata, Sachiko. (1996). Tao of Islam. Bandung: Mizan; h. 22

Pinem. Saroha. (2009). Kesehatan Reproduksi dan Kontrasepsi. Jakarta: Trans Media; h. 42 . L

Rusadi Kantaprawira (1999). Sistem Politik Indonesia; Suatu Model Pengantar , h. 56

Saputra, Fx. (2019). Partisipasi Politik Perempuan Naik https://www.kompas.id/baca/utama/2019/11/11/partisipasi-politikperempuan-naik/. Diakses tanggal 15 Juni 2021 
Surbakti, Ramlan (1999). Memahami Ilmu Politik.Jakarta. Gramedia Widisarana Indonesia, h. 117

TAP MPR No. II/MPR/1998, h. 798

Undang-Undang Nomor 12 Tahun 2005 tentang Pengesahan International Convenant on Civil and Political Rights, dan Undang-Undang Nomor 2 tahun 2008 tentang Partai Politik

Walkins (dkk). (2007). Feminisme Untuk Pemula. Yogyakarta: Resist Book h. 127 